\title{
Microbiological and formaline test on the big eye tuna (Thunnus obesus Lowe, 1839) from fish auction place (TPI) and moving fish trader (PIK) in Panimbang Pandeglang Village Banten
}

Lia Amelia Pertiwi ${ }^{1}$, Hadi Susilo ${ }^{2,}{ }^{*}$, Nurullah Asep Abdilah ${ }^{3}$

Biology Department, Faculty of Science, Pharmacy and Health, Universitas Mathla'ul Anwar, Banten, Indonesia

19meliapertiwi2998@gmail.com; 2 hadisusilo1973@gmail.com *;

3 nurullah.asep@gmail.com

* Corresponding author

\begin{tabular}{|c|c|}
\hline ARTICLE INFO & ABSTRACT \\
\hline $\begin{array}{l}\text { Article history } \\
\text { Submission May 10, } 2021 \\
\text { Revision May 28, } 2021 \\
\text { Accepted June 20, } 2021 \\
\text { Keyword } \\
\text { Coliform-Test } \\
\text { E. coli-Test } \\
\text { Formaldehyde-Test } \\
\text { Total Plate Count (TPC) }\end{array}$ & $\begin{array}{l}\text { Big Eye Tuna (Thunnus obesus Lowe, 1839) is one of the fish } \\
\text { species that have the potential to increase sources of animal } \\
\text { protein and has high economic value in the world of trade } \\
\text { because it is the second-largest export commodity after } \\
\text { shrimp. The purpose of this study was to test the content of } \\
\text { microbial and formalin contamination in the flesh of T. } \\
\text { obesus fish from the Fish Auction Place (TPI) and Mobile } \\
\text { Fish Trader (PIK) in Panimbang Village, Pandeglang, Banten. } \\
\text { The research was carried out from January } 2020 \text { to February } \\
2021 \text { at the Regional Technical Implementation Unit (UPTD) } \\
\text { Testing and Application of Quality of Fishery Products, } \\
\text { Department of Marine Affairs, and Fisheries of Banten } \\
\text { Province. This research is a descriptive laboratory study with } \\
\text { purposive sampling. Twelve samples of T. obesus fish } \\
\text { obtained from TPI (6 fishes) and PIK (6 fishes) were each } \\
\text { taken for } 25 \text { g of meat and then tested for microbial } \\
\text { contamination content with Total Plate Count (TPC) using } \\
\text { Butterfield's phosphate (BFP) media, and Plate Count Agar } \\
\text { (PCA), Coliform-Test and E. coli-Test using Lauryl Tryptose } \\
\text { Broth (LTB), Brilliant Green Lactose Bile (BGLB), EC Broth } \\
\text { and Levines Eosin Methylene Blue (LEMB) media as well as } \\
\text { Formaldehyde-Test using Formaldehyde-Test Kits. The } \\
\text { results showed that the flesh of T. obesus fish contained } \\
\text { microbial contamination with the average values of TPC, } \\
\text { Coliform MPN and E. coli MPN respectively, namely } 1.6103 \\
\text { colony/g, } 15.2 \text { MPN/g and < } 3 \text { MPN/g ( TPI) and } 1,7103 \\
\text { colony/g, } 61.3 \text { MPN/g and < } 3 \text { MPN/g (PIK). T. obesus fish } \\
\text { meat obtained from TPI and PIK proved to not contain } \\
\text { formalin. Fish in TPI and PIK are safe for consumption by the } \\
\text { community as stipulated in SNI } 2332.1: 2015 \text {. }\end{array}$ \\
\hline
\end{tabular}

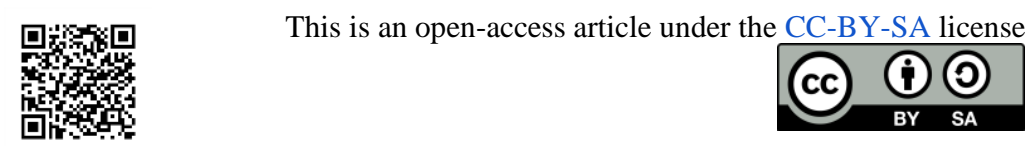

Conflict of interest: The authors declare that they have no conflicts of interest. 


\section{Introduction}

Fish is one of the marine products which is an important commodity of the world food sector. Indonesia's vast waters with very large fishery resources have the potential to provide healthy animal protein food for the world community ${ }^{1}$. T. obesus is one of the species that has the potential to increase animal protein sources, has high economic value in the world of trade and is the second-largest export commodity after shrimp ${ }^{2}$. BPS 2018 data, stated that the catch of marine fish was $6,701,834$ tons $^{3}$.

The distribution process of $\mathrm{T}$. obesus fish takes place in several stages and involves several parties. Fish Auction Place (TPI), which is a market that is usually located in a port/fish landing base, where fish/sea product sales transactions occur either by auction or not (not including TPI that sells/auctions land fish). After TPI, fish are distributed by several types of traders including fish traders at TPI and Mobile Fish Traders (PIK) ${ }^{3}$.

The decomposition process of $\mathrm{T}$. obesus takes place rapidly in the tropics because the temperature $\left(>27^{\circ} \mathrm{C}\right)$ and high humidity are ideal conditions for microbial growth and enzyme activity as well as chemical reactions that occur in the body. The decay process is accelerated through poor catching, improper handling, inadequate sanitation, and limited facilities, distribution, and marketing ${ }^{4-6}$. The level of microbial contamination in this study was much lower than the research conducted by Afandi the level of microbial contamination in TPI Lampulo (8.8x103CFU/g) is lower than that of fish distributed by mobile fish traders in Banda Aceh City $(1.1 \times 107 \mathrm{CFU} / \mathrm{g})^{3}$.

Determination of the quality of fresh fish through microbiological tests and formalin tests is very important to determine the quality so that it can prevent food poisoning due to contamination of pathogenic bacteria or foodborne disease (FBD) caused by microbes entering the body with food. This needs to be followed up with the latest research on the microbiological status and formalin (Coliform-Test, E. Coli-Test, Formaldehyde Test and Total Plate Count (TPC)) so that the quality of T. Obesus exported does not exceed the established quality standards ${ }^{7}$.

\section{Method}

\section{Material}

The materials used in this study were: Phosphate-Buffered dilution water (BFP), Plate Count Agar (PCA), Nutrient Agar, Peptone Water, Triptic Soy Agar (TSA), Brilliant Green Lactose Bile (BGLB), Lauryl Tryptose Broth (LTB), EC broth, Levine's Eosin Methylene Blue (LEMB), Tryptone Broth (TB), Simmon Citrate Agar (SCA), Lactose Broth (LB), 0.5\% peptone water solution, Kovac's reagent, sodium hydroxide; gram stain reagent.

\section{Work procedures \\ Total Plate Count (TPC)}

T. obesus meat as much as $25 \mathrm{~g}$ was weighed aseptically, then put in a sterile plastic bag. Then added $225 \mathrm{ml}$ of buffered dilution water (BFP) after that, homogenized with a stomacher for 1-2 minutes (dilution 10-1), then transferred $1 \mathrm{ml}$ of suspension with a 10-1 dilution into a test tube containing a solution of $9 \mathrm{ml}$ of BFP (dilution 10-2) and made a dilution of 10-1 - 106) after that it was poured into Petri dishes in duplicate, then 15-20 ml of cold PCA was added to each cup that already contained the suspension. Then the cup was rotated forward and backward or formed a figure eight after that, allowed to stand until it became solid, then incubated with an incubator at a temperature of $35^{\circ} \mathrm{C}$ for $24-48$ hours with the cup in an inverted position and the total number of colonies was calculated using a colony counter ${ }^{8}$. 


\section{Coliform-Test dan E.coli-Test}

T. obesus meat as much as $25 \mathrm{~g}$ was weighed aseptically, then put into a sterile plastic bag. Make sure the sample is not frozen. Then coded in a sterile plastic bag according to the code of origin of the sample. Then $225 \mathrm{ml}$ of buffered dilution water (BFP) was added after which it was homogenized with a stomacher for 1-2 minutes (10-1 dilution) ${ }^{8}$.

\section{Estimating Coliform-Test}

Prepare the 10-2 dilution by dissolving $1 \mathrm{ml}$ of the 10-1 solution into $9 \mathrm{ml}$ of the BFP diluent, after which the next dilution is homogenized with a stomacher for 1-2 minutes, transferred using a sterile pipette, $1 \mathrm{~mL}$ of the solution from each dilution into 3 Lauryl Tryptose Broth (LTB) tubes containing Durham tubes were then incubated at $35^{\circ} \mathrm{C}$. The gas formed was observed after 24 hours of incubation. The positive tube is characterized by turbidity and gas in the Durham tube. After that, it was incubated again using negative tubes for 24 hours and the results were recorded at 48 hours.

\section{Confirmation Coliform-Test}

Positive Lauryl Tryptose Broth (LTB) tubes were inoculated into Brilliant Green Lactose Bile (BGLB) tubes containing Durham tubes using an ose needle. then incubated Brilliant Green Lactose Bile (BGLB) which had been inoculated at 35 0C. After that, the positive tube is marked with turbidity and gas in the Durham tube. Then the most probable value (APM) for Coliform was determined based on the number of positive Brilliant Green Lactose Bile (BGLB) tubes using the Most Possible Number (APM). The coliform number is expressed as “APM/g”.

\section{Estimating E.coli-Test}

Inoculated from each positive Lauryl Tryptose Broth (LTB) tube into EC broth tubes containing Durham tubes using an ose needle. Then the EC broth was incubated in a circulating water bath for 48 hours at $45.5^{\circ} \mathrm{C}$. Then it is incubated with a sterile water bath and the water in it must be higher than the level of the liquid in the tube to be incubated. After that, check the tubes of EC broth that produces gas for 24 hours, if positive, incubate again and check at 48 hours. The positive tube is characterized by turbidity and gas in the Durham tube. Then the most probable value (APM) was determined based on the number of positive EC tubes using the APM. The fecal Coliform rate is expressed as “APM/g".

\section{Confirmation E.coli-Test}

From the positive Ec broth tubes using a needle, scratched onto Levine's Eosin Methylene Blue (LEMB) agar. Then it was incubated for 24 hours at $35^{\circ} \mathrm{C}$. The suspected E. coli colonies gave typical characteristics, namely black in the center, flat, and with or without metallic green.

\section{Results and Discussion}

\section{Total Plate Count (TPC)}

Based on the results of the test with the T. obesus fish meat sample presented in (Table 1), it shows that the TPC value in the T. obesus sample obtained at the TPI with a value of 1.610 3 (colony/g), contains lower contamination when compared with PIK, which is $1.710-3$ (colony/g).

The low level of microbial contamination in T. obesus fish sold at TPI is due to its fresh condition and immediately given special handling after being unloaded from fishing boats. Handling is fast, clean, careful and cold so that the quality of fish can be maintained since the fish is removed from the sea until the fish is distributed or marketed to consumers. The quality of fish is still following the standard of SNI 2332.1:2015, and is safe for consumption by the public. 
Table 1. Total Plate Count (TPC) on the T. obesus fish from the Fish Auction Place (TPI) and Mobile Fish Traders (PIK) in the Panimbang village, Pandeglang, Banten

\begin{tabular}{lcc}
\hline & TPC (colony/g) & Rerata TPC (colony/g) \\
\hline PIK 1 & $1.5 \times 10^{-5}$ & \\
PIK 2 & $1.8 \times 10^{-5}$ & \\
PIK 3 & $1.7 \times 10^{-3}$ & $1.610^{-5}$ \\
PIK 4 & $1.8 \times 10^{-5}$ & \\
PIK 5 & $1.6 \times 10^{-3}$ & \\
PIK 6 & $1.9 \times 10^{-5}$ & \\
TPI 1 & $1.6 \times 10^{-3}$ & \\
TPI 2 & $1.8 \times 10^{-5}$ & \\
TPI 3 & $1.4 \times 10^{-5}$ & \\
TPI 4 & $1.7 \times 10^{-3}$ & \\
TPI 5 & $1.7 \times 10^{-3}$ & \\
TPI 6 & $1.8 \times 10^{-5}$ & \\
\hline
\end{tabular}

\section{Coliform-Test}

Based on the results of the research on the presumption test (Figure 1) and (Table 1) it was found that all samples were positive, in PIK In samples 1, 2, 3, 4, 5, and 6 all tubes formed gas which indicated that the content of Coliform bacteria was higher large compared to the sample in PIK.

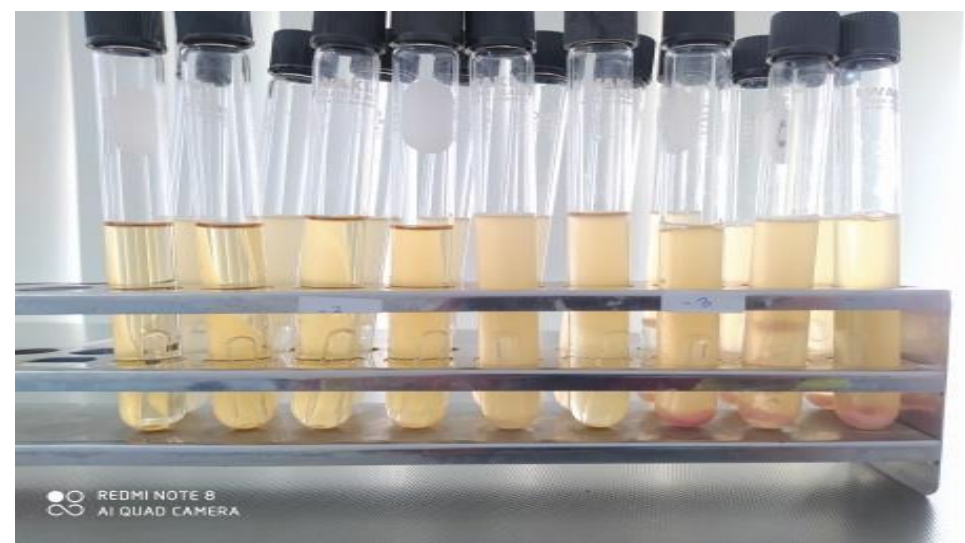

Fig 1. Coliform presumption test results on LTB media (The result is positive if there are gas bubbles)

Table 2. Data on MPN Coliform Presumption Test Results on Fish Meat of T. obesus from TPI and PIK in Panimbang Pandeglang Village, Banten

\begin{tabular}{lcccc}
\hline Sample & \multicolumn{2}{c}{ Number of Tubes Positive on Dilution } & Average TPC \\
\cline { 2 - 4 } & $\mathbf{1 0}^{-\mathbf{1}}$ & $\mathbf{1 0}^{-\mathbf{2}}$ & $\mathbf{1 0}^{-3}$ & (colony/g) \\
\hline PIK 1 & 2 & 1 & 0 & Positive \\
PIK 2 & 2 & 0 & 1 & Positive \\
PIK 3 & 1 & 2 & 1 & Positive \\
PIK 4 & 1 & 3 & 0 & Positive \\
PIK 5 & 2 & 0 & 0 & Positive \\
PIK 6 & 2 & 1 & 2 & Positive \\
TPI 1 & 3 & 1 & 0 & Positive \\
TPI 2 & 3 & 1 & 0 & Positive \\
TPI 3 & 3 & 3 & 3 & Positive \\
TPI 4 & 3 & 0 & 2 & Positive \\
TPI 5 & 2 & 2 & 2 & Positive \\
TPI 6 & 3 & 1 & 1 & Positive \\
\hline
\end{tabular}


Based on the results obtained in the confirmation test (Figure 2), it shows that all of the tested T. obesus samples do not meet the requirements and exceed the quality standard threshold that has been set by SNI 2332.1:2015 regarding the quality requirements of T. obesus which states that the maximum level of Coliform bacteria of $<3 \mathrm{MPN} / \mathrm{g}$. Based on the test results with samples of T. obesus fish meat, it shows that the MPN Coliform value in the T. obesus sample obtained at TPI with a value of 15.2 (MPN/g) contains lower contamination when compared to PIK, which is 61.3 (MPN/g). The more positive tubes, the lower the quality of the sample. On the other hand, the fewer positive tubes, the higher the quality of the sample ${ }^{9-11}$.

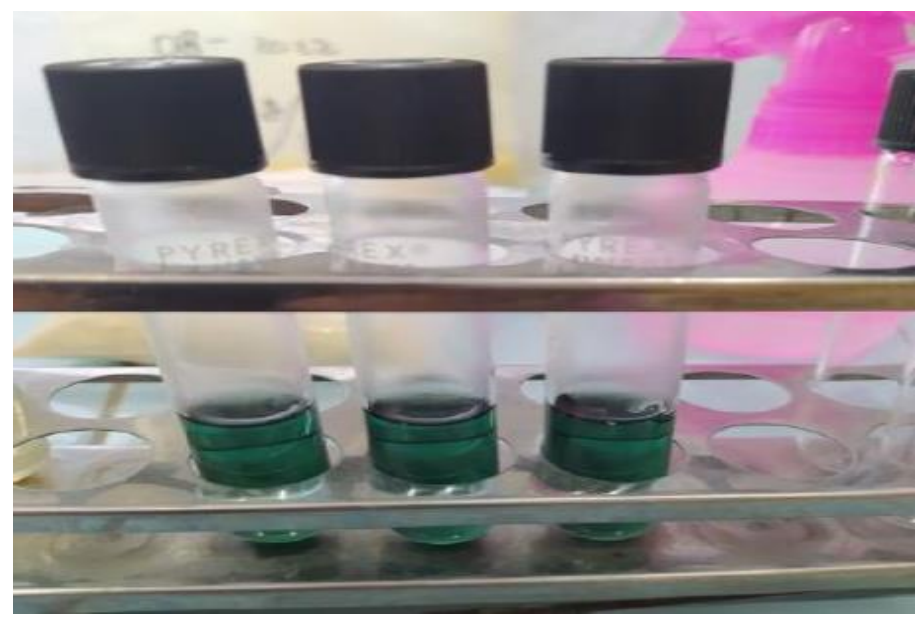

Fig 2. Coliform confirmation test results on BGLB media (positive results have gas bubbles)

\section{E. coli-Test}

The results of the presumptive test of E. coli bacteria using EC media. Broth. (Table 3) is a growth medium used in the first test to analyze E. coli bacteria. E. coli is a bacterium that can ferment lactose into gas and acid ${ }^{12}$. The results of the presumption test with E.C. media broth obtained negative results containing E. Coli because no gas was formed in each Durham tube.

Table 3. Data from the Presumption of MPN E. coli on T. obesus Fish Meat from TPI and PIK in Panimbang Pandeglang Village, Banten.

\begin{tabular}{lccccc}
\hline Sample & \multicolumn{2}{c}{ Number of Tubes Positive on Dilution } & Information & $\begin{array}{c}\text { Total } \boldsymbol{E} \text {. coli } \\
\text { MPN (MPN/g) }\end{array}$ \\
\cline { 2 - 3 } & $\mathbf{1 0}^{-\mathbf{1}}$ & $\mathbf{1 0}^{-\mathbf{2}}$ & $\mathbf{1 0}^{-\mathbf{3}}$ & & $<3$ \\
\hline PIK 1 & 0 & 0 & 0 & Negative & $<3$ \\
PIK 2 & 0 & 0 & 0 & Negative & $<3$ \\
PIK 3 & 0 & 0 & 0 & Negative & $<3$ \\
PIK 4 & 0 & 0 & 0 & Negative & $<3$ \\
PIK 5 & 0 & 0 & 0 & Negative & $<3$ \\
PIK 6 & 0 & 0 & 0 & Negative & $<3$ \\
TPI 1 & 0 & 0 & 0 & Negative & $<3$ \\
TPI 2 & 0 & 0 & 0 & Negative & $<3$ \\
TPI 3 & 0 & 0 & 0 & Negative & $<3$ \\
TPI 4 & 0 & 0 & 0 & Negative & $<3$ \\
TPI 5 & 0 & 0 & 0 & Negative & $<3$ \\
TPI 6 & 0 & 0 & 0 & Negative & \\
\hline
\end{tabular}

A confirmation test is a test that is carried out after a presumption test to distinguish E. Coli bacteria (Table 4) The confirmation test uses LEMB agar media and samples that are strained from the results of the EC test Broth. 
Table 4. Data from the Confirmation test of MPN E. coli on T. obesus Fish Meat from TPI and PIK in Panimbang Pandeglang Village, Banten

\begin{tabular}{|c|c|c|c|c|c|}
\hline \multirow{2}{*}{ Sample } & \multicolumn{3}{|c|}{ Number of Tubes Positive on Dilution } & \multirow{2}{*}{ Information } & \multirow{2}{*}{$\begin{array}{l}\text { Total Coliform } \\
\text { MPN (MPN/g) }\end{array}$} \\
\hline & $10^{-1}$ & $10^{-2}$ & $10^{-3}$ & & \\
\hline PIK 1 & 2 & 2 & 0 & Positif & 9.2 \\
\hline PIK 2 & 1 & 2 & 1 & Positif & 15 \\
\hline PIK 3 & 1 & 2 & 1 & Positif & 15 \\
\hline PIK 4 & 1 & 2 & 1 & Positif & 15 \\
\hline PIK 5 & 2 & 0 & 0 & Positif & 9.2 \\
\hline PIK 6 & 2 & 2 & 1 & Positif & 28 \\
\hline TPI 1 & 3 & 2 & 0 & Positif & 93 \\
\hline TPI 2 & 2 & 2 & 0 & Positif & 21 \\
\hline TPI 3 & 3 & 1 & 0 & Positif & 43 \\
\hline TPI 4 & 3 & 1 & 1 & Positif & 75 \\
\hline TPI 5 & 3 & 1 & 0 & Positif & 43 \\
\hline TPI 6 & 3 & 2 & 0 & Positif & 93 \\
\hline
\end{tabular}

LEMB or Levines Eosin Methylene Blue agar is a differential selective medium used to identify and differentiate E. Coli bacteria (Figure 3).
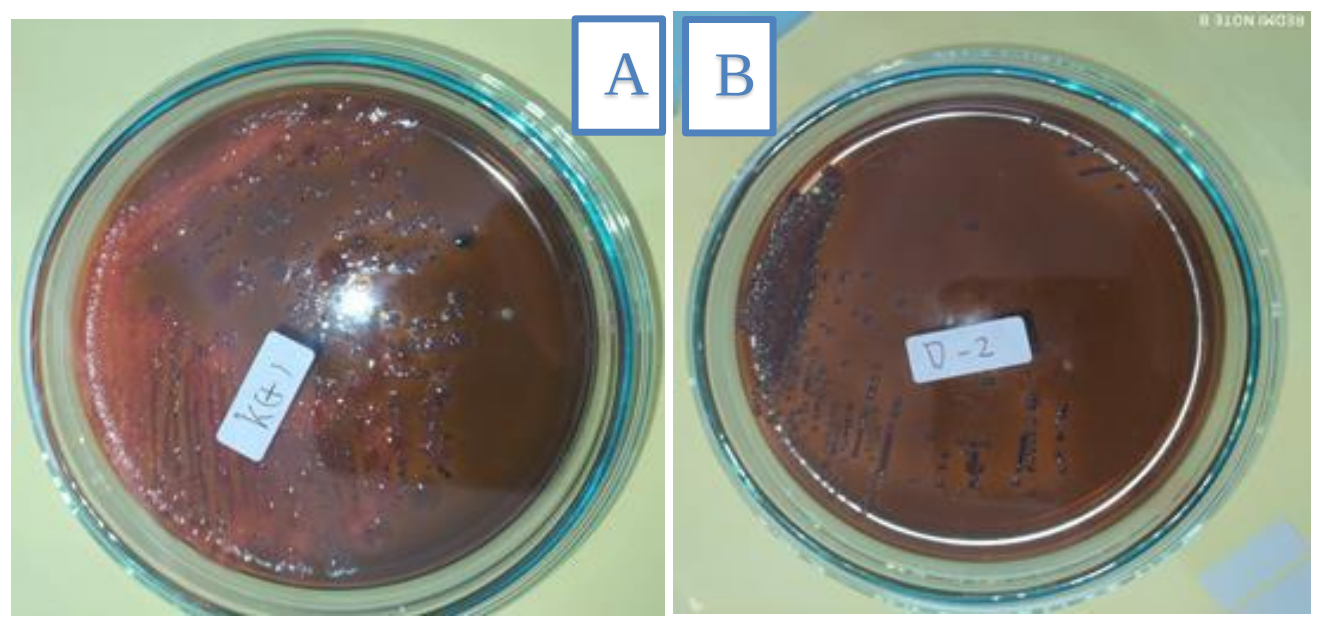

Fig 3. Confirmation test results on LEMB media. Remarks: (A) The media control cup has no metallic color; (B) The solvent cup does not have a metallic color

Based on the results obtained, E.coli colonies did not grow with black or dark characteristics in the center of the colony with or without greenish metallic. Based on the test results with samples of T. obesus fish meat (Table 3), it shows that the MPN value of E. Coli in the T. obesus samples obtained in TPI and PIK with a value of $<3$ (MPN/g) this indicates that the sample T. obesus obtained at TPI and PIK were not contaminated with E. coli or in good quality condition. This value meets the quality standards set by SNI 2332.1:2015 regarding quality requirements, which states that the maximum level of E. coli bacteria is $<3$ MPN/g. The results of the research by Mailoa showed that smoked tuna loin from Air Manis Hamlet, Laha Village met the microbiological standard for E. coli at a maximum of $<3 \mathrm{MPN} / \mathrm{g}$, because the results obtained were negative for E. coli ${ }^{7}$.

\section{Formaldehyde-Test}

From the results of the Formaldehyde-Test on samples of T. obesus distributed in TPI and PIK Panimbang Pandeglang Banten Village (Table 5) it was found that 5 samples of T. obesus did not contain formalin because they did not change color to purple. 
Table 5. Data of formalin test results on fish meat of T. obesus from TPI and PIK in Panimbang Pandeglang Village, Banten

\begin{tabular}{lll}
\hline \multicolumn{1}{c}{ Sample } & \multicolumn{1}{c}{ Observation results } & Description \\
\hline PIK 1 & No color change occurs & Negative \\
PIK 2 & No color change occurs & Negative \\
PIK 3 & No color change occurs & Negative \\
PIK 4 & No color change occurs & Negative \\
PIK 5 & No color change occurs & Negative \\
PIK 6 & No color change occurs & Negative \\
TPI 1 & No color change occurs & Negative \\
TPI 2 & No color change occurs & Negative \\
TPI 3 & No color change occurs & Negative \\
TPI 4 & No color change occurs & Negative \\
TPI 5 & No color change occurs & Negative \\
TPI 6 & No color change occurs & Negative \\
\hline
\end{tabular}

The results of this test indicate that T. obesus samples distributed in TPI and PIK Panimbang Pandeglang Banten are safe for public consumption because both TPI and PIK have complied with Government Regulations concerning the Prohibition of the Addition of Formalin to food and indicates that TPI and PIK use natural preservatives (ice cubes) in T. obesus fish.

\section{Conclusion}

T. obesus fish meat samples from Fish Auction Place (TPI) and Mobile Fish Trader (PIK) in Panimbang Pandeglang Village, Banten contain microbial contamination based on Total Plate Count (TPC), Coliform-Test and E. coli-Test tests. T. obesus fish meat samples from Fish Auction Places (TPI) and Mobile Fish Traders (PIK) in Panimbang Pandeglang Village, Banten contain different amounts of microbial contamination, at TPI the TPC value is 1.6103 colony/g, Coliform 15.2 MPN /g and E. coli < $3 \mathrm{MPN} / \mathrm{g}$. And in PIK the TPC value is 1.7103 colony/g, Coliform 61.3 MPN/g and E. coli < $3 \mathrm{MPN} / \mathrm{g}$ (PIK). T. obesus fish meat samples from Fish Auction Places (TPI) and Mobile Fish Traders (PIK) in Panimbang Pandeglang Village, Banten as a whole meet the quality standards set out in SNI 2332.1:2015., and are safe for consumption for the community.

\section{References}

1. Wodi, S. I. M., Rieuwpassa, F. J. \& Cahyono, E. Peningkatan kualitas hasil tangkapan melalui penerapan sistem rantai dingin di kelurahan Santiago. J. Ilm. Tatengkorang 2, 70-72 (2018).

2. Cahyono, E., Rahmatu, R., Ndobe, S. \& Mantung, A. Ekstraksi dan karakterisasi gelatin tulang tuna pada berbagai konsentrasi enzim Papain. Fishtech - J. Teknol. Has. Perikan. 7, 148-153 (2018).

3. Affandi, R. P., Ferasyi, T. R. \& Karina, S. Uji mikrobiologi ikan tongkol (Euthynnus affinis) yang didistribusikan di Tempat Pelelangan Ikan (TPI) Lampulo dan oleh Pedagang Ikan Keliling (PIK) di kota Banda Aceh. J. Ilm. Mhs. Kelaut. dan Perikan. Unsyiah 1, 318-324 (2016).

4. Wodi, S. I. M., Trilaksani, W. \& Nurilmala, M. Changesin myoglobin of big eye tuna during chilling storage. J. Pengolah. Has. Perikan. Indones. 17, 215-224 (2014).

5. Bharti, A. Supply chain management and strategy implementation for perishable goods. in Supply Chain and Logistics Management 284-302 (IGI Global, 2020). doi:10.4018/978-1-7998-0945-6.ch014. 
6. Getu, A. \& Misganaw, K. Post-harvesting and major related problems of fish production. Fish. Aquac. J. 06, (2015).

7. Mailoa, M. N., Lokollo, E., Nendissa, D. M. \& Harsono, P. I. Karakteristik mikrobiologi dan kimiawi ikan tuna asap. J. Pengolah. Has. Perikan. Indones. 22, 89-99 (2019).

8. Badan Standarisasi Nasional. Cara uji mikrobiologi - Bagian 3: Penentuan Angka Lempeng Total (ALT) pada produk perikanan. (2015).

9. Adityawarman. Analisis bakteri coliform dalam produk es batu kemasan dari 5 usaha mikro dengan metode Most Probable Number (Mpn) di Kecamatan Danurejan, Yogyakarta. (Universitas Sanata Dharma, 2012).

10. Kamelia, M., Anggoro, B. S. \& Sa’adah, F. P. Analisis kualitas es batu berdasarkan kandungan coliform di kantin UIN Raden Intan Lampung. Biosf. J. Tadris Biol. 9, 61 (2018).

11. Khotimah, L. Analisis cemaran bakteri coliform dan identifikasi escherichia coli pada es batu kristal dan es balok di Kelurahan Cibubur Jakarta Timur Tahun 2016. (UIN Syarif Hidayatullah, 2016).

12. Budiono, H., Harlis \& Retni, S. B. Analisis ambang batas Escherichia coli sebagai indikator pencemaran pada daging sapi di rumah pemotongan hewan kota Jambi. Biospecies 5, 14-21 (2012).

\section{Author contributions}

All authors contributed to the study's conception and design. Material preparation, data collection and analysis were performed by all authors. The first draft of the manuscript was written by the first author and all authors commented on previous versions of the manuscript. All authors read and approved the final manuscript. 